\title{
Penggunaan asam sulfat sebagai aktivator fly ash dalam aplikasi proses koagulasi pada pengolahan limbah cair industri pulp dan kertas
}

\author{
Nurul Ajeng Susilo ${ }^{1 *}$, Noviea Sulistyawati ${ }^{1}$ \\ ${ }^{1}$ Program Studi Teknologi Pengolahan Pulp dan Paper, Fakultas Vokasi, Institut Teknologi dan Sains Bandung \\ ${ }^{1}$ Corresponding author: nurulajeng20@gmail.com
}

\begin{abstract}
Abstrak. Pada penelitian ini dilakukan pemanfaatan abu layang batubara (fly ash) yang diaktivasi oleh asam sulfat sebagai koagulan pada pengolahan limbah cair pulp dan kertas. Tujuan dari penelitian ini adalah untuk mengetahui kemampuan $\mathrm{H} 2 \mathrm{SO} \neg 4$ dalam mengaktivasi abu layang batubara, menentukan aktivasi optimum abu layang batubara sebagai koagulan, serta menentukan dosis optimum penambahan koagulan abu layang batubara teraktivasi dalam proses pengolahan limbah cair pulp dan kertas. Abu layang batubara diaktivasi dengan menggunakan $\mathrm{H} 2 \mathrm{SO} 4$ dengan 9 macam variasi aktivasi. Kondisi optimum didapatkan pada pemanasan $250 \mathrm{oC}$, selama 60 menit, dengan rasio perbandingan asam sulfat : abu laying sebesar 1:5 dan konsentrasi H2SO4 2M. Selanjutnya, koagulan cair pada kondisi optimum dilakukan uji efektivitas pada proses pengolahan limbah cair pulp dan kertas. Parameter yang diukur yaitu COD, TSS, warna, kekeruhan dan konduktivitas. Dosis optimum koagulan abu layang teraktivasi yaitu pada dosis $30000 \mathrm{ppm}$ dengan penurunan COD sebesar $81,5 \%$, TSS sebesar $96,2 \%$, warna sebesar $86,5 \%$, dan kekeruhan sebesar 99,3\%. Penambahan koagulan abu layang teraktivasi menimbulkan kenaikan nilai konduktivitas air limbah hasil koagulasi.
\end{abstract}

Keywords: asam sulfat, aktivasi abu layang, koagulan

\section{Pendahuluan}

Abu layang batubara (coal fly ash) adalah material yang memiliki ukuran butiran yang halus berwarna keabu-abuan dan diperoleh dari hasil pembakaran batubara (Wardani, 2008). Di Imdonesia, produksi limbah abu dasar dan abu layang batubara dari tahun ke tahun meningkat sebanding dengan konsumsi penggunaan batubara sebagai bahan baku pada industri PLTU (Harijono D, 2006, dalam Irwanto, 2010). Abu layang batubara merupakan abu yang dihasilkan dari proses pelelehan atau gasifikasi dan transformasi dari material organik yang terkandung di dalam batubara. Proses pembakaran batubara menghasilkan abu layang (fly ash) sekitar $80 \%$ dan sisanya adalah abu dasar (bottom ash) sekitar 20\%. Menurut Peraturan Pemerintah PP101/2014 limbah abu layang maupun abu dasar dapat dikategorikan sebagai limbah B3 (bahan berbahaya dan beracun) yang perlu dilakukan penanganan limbah sebelum dibuang ke lingkungan (Retnosari, 2013). Pada industri pulp dan kertas, air merupakan salah satu kebutuhan produksi yang harus dijaga kualitas dan kuantitasnya. Selain pada proses produksi hal tersebut berdampak pada lingkungan dengan kurangnya penjagaan mutu pada pengolahan limbah industri yang dibuang ke lingkungan, sehingga mengakibatkan permasalahan lingkungan yang kompleks.

Kandungan oksida Al dan Fe pada abu layang berpotensi untuk dimanfaatkan sebagai koagulan. Koagulan berbasis $\mathrm{Al}$ dan Fe telah banyak dikenal dan digunakan dalam proses pengolahan air ataupun limbah cair karena mampu mengikat partikel-partikel koloid, zat organik dan pengotor di dalam air.

Dari penelitian yang telah dilakukan oleh para peneliti, belum ada penelitian yang membahas mengenai aplikasi abu terbang batubara sebagai koagulan dalam pengolahan limbah cair indutri pulp dan kertas. 


\section{Metodologi}

\subsection{Bahan dan reagen}

Bahan kimia dan reagen yang digunakan dalam penelitian ini yaitu Asam sulfat $\left(\mathrm{H}_{2} \mathrm{SO}_{4}\right) 96 \%$, natrium hidroksida $(\mathrm{NaOH}) 30 \%$ p.a., Aqua demineralisasi dan air limbah industri pulp dan kertas juga digunakan dalam percobaan ini sebagai aplikasi dari abu layang teraktivasi. Komposisi dari abu layang ditampilkan pada Tabel 1.

Tabel 1. Komposisi Kimia Abu Layang Batubara

dari Industri Pulp dan Kertas Sebelum Aktivasi

\begin{tabular}{|c|c|}
\hline Komposisi Kimia & Kadar (\%) \\
\hline $\mathrm{SiO}_{2}$ & 62,26 \\
\hline $\mathrm{Al}_{2} \mathrm{O}_{3}$ & 22,43 \\
\hline $\mathrm{Fe}_{2} \mathrm{O}_{3}$ & 3,78 \\
\hline $\mathrm{CaO}$ & 5,89 \\
\hline $\mathrm{SO}_{3}$ & 3,88 \\
\hline $\mathrm{K}_{2} \mathrm{O}$ & 0,88 \\
\hline $\mathrm{TiO}_{2}$ & 0,70 \\
\hline $\mathrm{SrO}$ & 0,10 \\
\hline $\mathrm{ZnO}$ & 0,09 \\
\hline
\end{tabular}

\subsection{Alat penelitian dan pengujian}

Alat yang digunakan dalam penelitian ini adalah gelas beker, erlenmeyer, labu ukur, gelas ukur, pipet volume, pipet skala, pipet tetes, ball pipet, pengaduk, cawan porselen, kertas saring whatman ukuran 42, pengaduk magnetik, corong buchner, neraca analitik, kondensor refluks, hotplate, oven, centrifuge, desikator, dan termometer.

Instrumen yang digunakan untuk penelitian ini adalah VELP - scientifica JLT4 Jartester, spectrometer Hach DR 500, turbidimeter, pH meter, microXRF-EDAX TSL, ICP-OES Spectrometer (Agilent 710) dan SEM.

\subsection{Prosedur penelitian}

Penelitian ini dilaksanakan dalam dua tahapan dengan menggunakan metode eksperimen, tahapan pertama adalah proses aktivasi abu layang (fly ash) sebagai koagulan cair dengan menggunakan pelarut asam sulfat $\left(\mathrm{H}_{2} \mathrm{SO}_{4}\right)$. Penentuan kondisi pelindian optimum berdasarkan penelitian yang telah dilakukan oleh Li et al., (2011) dan Safutra, Amin dan Anita (2017) dengan memvariasikan temperatur, waktu, rasio dan konsentrasi pelarut. Koagulan yang didapatkan dari setiap kombinasiperlakuan dianalisis dengan ICP-OES spectrometer, selanjutnya dihitung \% yield $\mathrm{Al}$ dan $\mathrm{Fe}$ yang terekstrak.

Tahapan kedua adalah proses koagulasi limbah cair pulp dan kertas dengan koagulan cair. Penelitian ini dilakukan dengan memvariasikan dosis koagulan cair yang diberikan yaitu: 10000 ppm, 15000 ppm, 20000 ppm, 25000 ppm, 30000 ppm, 35000 ppm, 40000 ppm, 45000 ppm dan 50000 ppm.

\subsection{Parameter penelitian}

Parameter penelitian yang diamati adalah karakteristik air limbah meliputi : COD, TSS, warna, kekeruhan, dan konduktivitas. COD diukur berdasarkan metode SNI 06-6989.15-2004 dan pengukuran TSS dilakukan berdasarkan SNI 06-6989.3-2004. 


\section{Hasil dan pembahasan}

\subsection{Aktivasi abu laying dengan pelarut asam sulfat $\left(\mathrm{H}_{2} \mathrm{SO}_{4}\right)$}

Abu layang batubara yang digunakan dalam penelitian ini berasal dari multi boiler, Abu layang batubara yang didapatkan berupa butiran-butiran halus, berukuran $200 \mu \mathrm{m}$ dengan warna abu-abu kebiruan. Berdasarkan American National Standards yang diterbitkan oleh the American Society for Testing and Materials (ASTM) C 618, abu layang dapat digolongkan menjadi dua kelas berdasarkan adanya perbedaan komposisi kimia yaitu abu layang tipe $\mathrm{C}$ dan abu layang tipe F. Dengan memperhatikan Tabel 1 diatas, maka abu layang multi boiler pada industri pulp dan kertas ini tergolong dalam tipe F. Hal ini sesuai dengan Sukandarrumidi (2009), yang menjelaskan bahwa abu layang tipe $\mathrm{F}$ mengandung kalsium oksida $(\mathrm{CaO})$ kurang dari $10 \%$ serta mengandung lebih dari $70 \% \mathrm{SiO}_{2}, \mathrm{Al}_{2} \mathrm{O}_{3}$, dan $\mathrm{Fe}_{2} \mathrm{O}_{3}$. Abu layang tipe $\mathrm{F}$ dihasilkan dari pembakaran batubara jenis anthracite dan bituminous. Pada hasil XRF diketahui bahwa kandungan $\mathrm{Fe}_{2} \mathrm{O}_{3}$ dan $\mathrm{Al}_{2} \mathrm{O}_{3}$ dalam abu layang cukup besar yang memungkinkan abu layang digunakan sebagai koagulan. Kedua senyawa tersebut yang akan dimanfaatkan untuk diaktifkan menggunakan asam sulfat menjadi koagulan. Menurut Fan dkk. (2005), proses aktivasi yang dilakukan mampu mengubah besi oksida dan aluminium oksida dalam abu layang batubara menjadi bentuk $\mathrm{Fe}^{3+}$ dan $\mathrm{Al}^{3+}$ yang mana lebih bebas berikatan dengan partikel tidak larut dalam limbah.

Pada tahap persiapan, abu layang yang diperoleh di oven terlebih dahulu pada temperatur $105^{\circ} \mathrm{C}$ selama 12 jam. Hal tersebut bertujuan untuk menghilangkan kandungan air dalam abu layang (Irani, 2009). Selanjutnya abu layang diayak dengan menggunakan saringan berukuran 200 mesh untuk mendapatkan ukuran partikel yang lebih kecil dan homogen. Ukuran partikel abu layang yang lebih kecil dapat memperbesar luas permukaan abu layang, sehingga semakin banyak abu yang dapat berekasi dengan aktivator $\left(\mathrm{H}_{2} \mathrm{SO}_{4}\right)$.

Proses pengaktifan dilakukan dengan mencampurkan abu layang batubara dalam $\mathrm{H}_{2} \mathrm{SO}_{4}$ dengan variasi konsentrasi, temperatur, waktu dan perbandingan abu layang dengan $\mathrm{H}_{2} \mathrm{SO}_{4}$ (Safutra, 2017). Menurut Fan dkk. (2005), larutan asam sulfat dapat digunakan untuk bereaksi dengan Al dan Fe dalam abu layang batubara, sehingga dapat menghasilkan ikatan polimer yang kuat. Hasil aktivasi abu layang batubara dipisahkan padatan dan cairannya dengan menggunakan centrifuge. Cairan/supernatan hasil aktivasi abu layang kemudian dilakukan tes ICP untuk melihat kandungan $\mathrm{Al}^{3+}$ dan $\mathrm{Fe}^{3+}$ dalam bentuk $\mathrm{Al}_{2}(\mathrm{SO} 4)_{3}$ dan $\mathrm{Fe}_{2}\left(\mathrm{SO}_{4}\right)_{3}$ yang merupakan bahan koagulan yang banyak dipakai dalam pengolahan limbah.

Cairan hasil aktivasi abu layang dengan $\mathrm{H}_{2} \mathrm{SO}_{4}$ kemudian dianalisa dengan ICP untuk mengetahui yield $\mathrm{Al}$ dan Fe hasil aktivasi abu layang batubara. Hasil perhitungan \% yield kation $\mathrm{Al}$ dan kation $\mathrm{Fe}$ seperti tercantum dalam Tabel 2.

Tabel 2. Yield $\mathrm{Al}$ dan Fe dengan Pelarut Asam Sulfat $\left(\mathrm{H}_{2} \mathrm{SO}_{4}\right)$

\begin{tabular}{|c|c|c|c|c|c|c|}
\hline \multirow[b]{2}{*}{ No } & \multicolumn{4}{|c|}{ Variasi } & \multicolumn{2}{|c|}{ Yield $(\%)$} \\
\hline & $\begin{array}{c}\text { Temperatur } \\
\left({ }^{\circ} \mathrm{C}\right)\end{array}$ & $\begin{array}{l}\text { Waktu } \\
\text { (menit) }\end{array}$ & Rasio & $\begin{array}{c}\text { Konsentrasi } \\
\text { (M) }\end{array}$ & $\mathrm{Al}$ & $\mathrm{Fe}$ \\
\hline 1 & 200 & 40 & $1: 3$ & 2 & 22,70 & 7,49 \\
\hline 2 & 200 & 60 & $1: 4$ & 4 & 27,33 & 13,35 \\
\hline 3 & 200 & 80 & $1: 5$ & 6 & 30,47 & 16,56 \\
\hline 4 & 250 & 40 & $1: 4$ & 6 & 27,60 & 14,20 \\
\hline 5 & 250 & 60 & $1: 5$ & 2 & 38,87 & 14,50 \\
\hline 6 & 250 & 80 & $1: 3$ & 4 & 9,09 & 4,93 \\
\hline 7 & 300 & 40 & $1: 5$ & 4 & 33,31 & 15,82 \\
\hline 8 & 300 & 60 & $1: 3$ & 6 & 10,31 & 7,10 \\
\hline 9 & 300 & 80 & $1: 4$ & 2 & 28,42 & 9,79 \\
\hline
\end{tabular}

Kondisi optimum proses aktivasi abu layang dengan menggunakan pelarut asam sulfat $\left(\mathrm{H}_{2} \mathrm{SO}_{4}\right)$ diperoleh pada temperatur $250^{\circ} \mathrm{C}$, waktu 60 menit, rasio abu layang dengan pelarut $1: 5$ dan konsentrasi pelarut $2 \mathrm{M}$ dengan masing-masing yield kation $\mathrm{Al}$ dan Fe yang terekstrak adalah 38,87\% dan 14,5\%. 
Menurut Fan dkk. (2005) dan Li, Wu, Liu, dan Zhai (2011) merumuskan reaksi aktivasi abu layang untuk mengubah besi(III) oksida dan alumina menjadi $\mathrm{Fe}^{3+}$ dan $\mathrm{Al}^{3+}$ dalam bentuk besi(III) sulfat dan aluminium sulfat dengan menggunakan asam sulfat $\left(\mathrm{H}_{2} \mathrm{SO}_{4}\right)$. Pada proses leaching asam, reaksi berikut akan terjadi.

$\mathrm{Al}_{2} \mathrm{O}_{3}(\mathrm{~s})+3 \mathrm{H}_{2} \mathrm{SO}_{4}(\mathrm{l}) \rightarrow \mathrm{Al}_{2}\left(\mathrm{SO}_{4}\right)_{3}(\mathrm{~s})+3 \mathrm{H}_{2} \mathrm{O}(\mathrm{g})$,

$\mathrm{Fe}_{2} \mathrm{O}_{3}(\mathrm{~s})+3 \mathrm{H}_{2} \mathrm{SO}_{4}(\mathrm{l}) \rightarrow \mathrm{Fe}_{2}\left(\mathrm{SO}_{4}\right)_{3}(\mathrm{~s})+3 \mathrm{H}_{2} \mathrm{O}(\mathrm{g})$

Morfologi abu layang pada skala mikro diamati dengan menggunakan Scanning Electron Microscopy (SEM). Morfologi abu layang batubara sesudah aktivasi ditunjukkan pada Gambar 1.

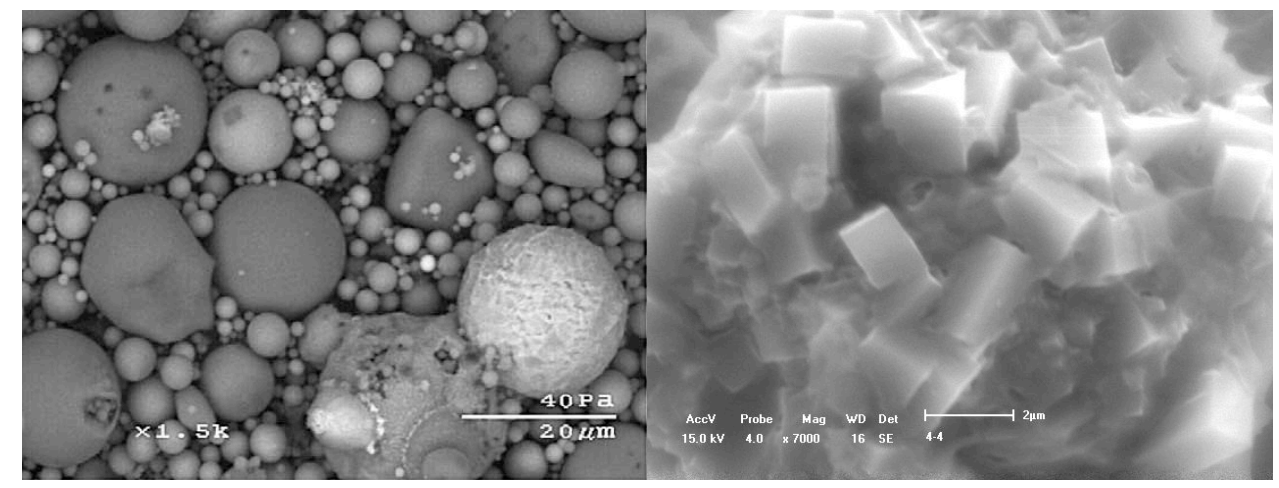

Gambar 1. Morfologi abu layang batubara sebelum aktivasi dengan $\mathrm{H}_{2} \mathrm{SO}_{4}$ perbesaran 1500 kali (kiri)

sesudah aktivasi perbesaran 7000 kali (kanan)

Pada abu layang yang telah teraktivasi dengan $\mathrm{H}_{2} \mathrm{SO}_{4}$ ini tampak bahwa abu layang diselimuti oleh kristalkristal dengan panjang $2 \mu \mathrm{m}$. Tampak kristal berbentuk batang mengelilingi permukaan abu layang, kristal yang mengelilingi merupakan kristal alum yang dihasilkan dari proses leaching dengan asam sulfat.

Proses aktivasi bertujuan untuk menghancurkan lapisan permukaan partikel abu layang yang berbentuk glassy sangat rapat dan stabil. Rantai glassy tersebut memiliki kandungan Al dan Fe yang tinggi. Oleh karena itu lapisan permukaan abu layang batubara yang berbentuk glassy ini harus dihancurkan agar gugus aktif didalamnya yang berpori dan amorf serta memiliki aktifitas tinggi keluar ke permukaan abu layang batubara.

\subsection{Karakterisasi air limbah}

Sampel efluen yang digunakan dalam penelitian ini merupakan hasil samping dari proses pembuatan pulp yang dikelantang. Titik pengambilan sampel efluen penelitian dilakukan pada inlet IPAL dari proses menuju ke bak penyetaraan (equalization tank). Data hasil karakterisasi efluen dari industri pulp dan kertas dapat dilihat di Tabel 3, sebagai berikut.

Tabel 3. Data Hasil Pengujian Karakterisasi Efluen

\begin{tabular}{|c|c|c|c|c|c|c|}
\hline \multirow{2}{*}{ Sumber } & \multicolumn{5}{|c|}{ Parameter Pengujian Sampel Air Limbah IPAL } \\
\cline { 2 - 7 } & $\mathrm{pH}$ & $\begin{array}{c}\text { COD } \\
(\mathrm{mg} / \mathrm{L})\end{array}$ & $\begin{array}{c}\text { Warna } \\
(\mathrm{ppm} \\
\text { PtCo })\end{array}$ & $\begin{array}{c}\text { Kekeruhan } \\
(\mathrm{NTU})\end{array}$ & $\begin{array}{c}\text { TSS } \\
(\mathrm{mg} / \mathrm{L})\end{array}$ & $\begin{array}{c}\text { Konduktivitas } \\
(\mu \mathrm{S} / \mathrm{cm})\end{array}$ \\
\hline $\begin{array}{c}\text { Inlet } \\
\text { IPAL }\end{array}$ & 7,14 & 1568,74 & 1040 & 202 & 379,6 & 87,8 \\
\hline
\end{tabular}

Muatan dari sampel limbah yang digunakan juga harus dicek untuk memastikan keberhasilan proses koagulasi-flokulasi. Dari hasil pengujian muatan pada sampel, diketahui bahwa sempel efluen yang digunakan bermuatan negatif. Hal ini dikemukakan oleh Vesilind et al.(1994) yang menyatakan bahwa partikel koloid mempunyai muatan. Koloid pada umumnya bermuatan negatif, sehingga tidak mungkin akan mengendap dengan sendirinya karena besarnya gaya tolak-menolak antar partikel koloid. 


\subsection{Penentuan dosis optimum koagulan abu layang teraktivasi}

Hasil aktivasi abu layang optimum yang telah didapatkan berdasarkan hasil pengujian ICP kemudian digunakan sebagai koagulan cair.

Tabel 4. Hasil Penelitian Dosis Koagulan Optimum

\begin{tabular}{|c|c|c|c|c|c|c|}
\hline \multirow{2}{*}{ No } & \multirow{2}{*}{$\begin{array}{c}\text { Dosis } \\
(\mathrm{ppm})\end{array}$} & \multicolumn{4}{|c|}{ Parameter Hasil Pengujian Setelah Penambahan Koagulan } & \\
\cline { 3 - 7 } & $\begin{array}{c}\text { COD } \\
(\mathrm{mg} / \mathrm{L})\end{array}$ & $\begin{array}{c}\text { Warna } \\
(\mathrm{ppm} \text { Pt Co })\end{array}$ & $\begin{array}{c}\text { Turbiditas } \\
(\mathrm{NTU})\end{array}$ & $\begin{array}{c}\text { TSS } \\
(\mathrm{mg} / \mathrm{L})\end{array}$ & $\begin{array}{c}\text { Konduktivitas } \\
(\mu \mathrm{S} / \mathrm{cm})\end{array}$ \\
\hline 1 & 10000 & 1081,3 & 580 & 78,6 & 143,2 & 6220 \\
\hline 2 & 15000 & 800,96 & 360 & 46,8 & 49,6 & 7290 \\
\hline 3 & 20000 & 788,4 & 230 & 4,01 & 33 & 11480 \\
\hline 4 & 25000 & 716 & 180 & 1,43 & 23,5 & 11800 \\
\hline $\mathbf{5}$ & $\mathbf{3 0 0 0 0}$ & $\mathbf{2 8 9 , 6}$ & $\mathbf{1 4 0}$ & $\mathbf{1 , 3 9}$ & $\mathbf{1 4 , 5}$ & $\mathbf{1 2 8 3 0}$ \\
\hline 6 & 35000 & 434,42 & 130 & 1,58 & 20,4 & 13050 \\
\hline 7 & 40000 & 584,7 & 130 & 3,95 & 25,6 & 13120 \\
\hline 8 & 45000 & 604,73 & 110 & 5,62 & 29 & 15800 \\
\hline 9 & 50000 & 679,8 & 120 & 4,8 & 32,5 & 17940 \\
\hline
\end{tabular}

Dosis koagulan cair yang paling efektif dalam meningkatkan kualitas air limbah dari Influen IPAL Pulp dan kertas adalah pada variasi nomor 5 dengan pemakaian dosis koagulan sebesar 30000 ppm. Air limbah hasil uji coba variasi perlakuan tersebut tersaji pada Gambar 2.

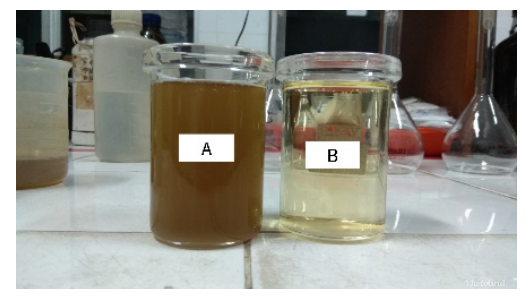

Gambar 2. Air Hasil Olahan dengan Dosis Optimum.

$(\mathrm{A}=$ Air Limbah Infulen IPAL, B= Air Hasil Olahan $)$

\subsection{Pengaruh penambahan kagulan abu laying teraktivasi terhadap nilai COD}

Efektifitas koagulasi berdasarkan pengurangan COD menyatakan persen penyisihan senyawa-senyawa organik akibat proses koagulasi.

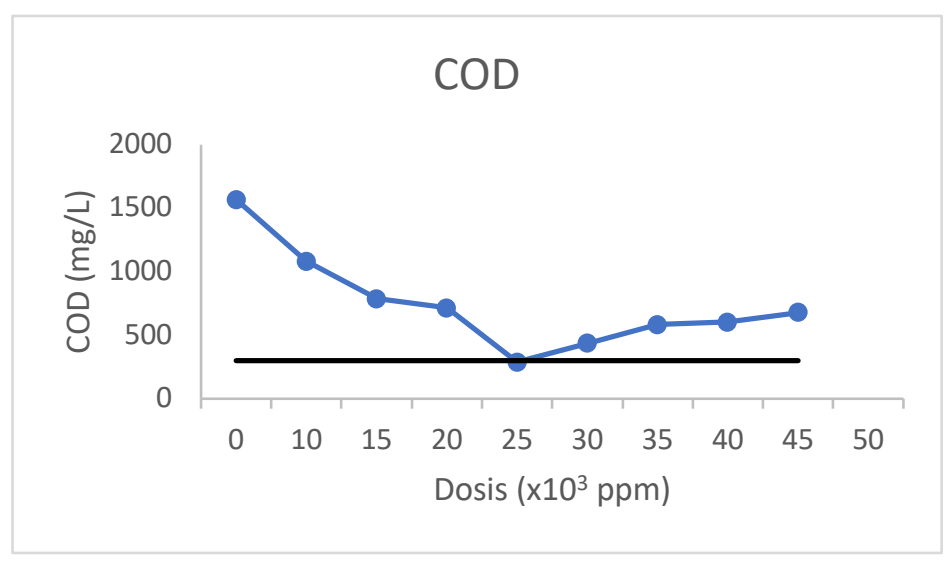

Gambar 3. Grafik Penurunan Nilai COD

Akibat Penambahan Koagulan Abu Layang Teraktivasi 
Dosis optimum penggunaan koagulan abu layang teraktivasi adalah pada konsentrasi $30000 \mathrm{ppm}$. Berdasarkan Gambar 3, Nilai COD yang meningkat seiring kenaikan dosis melebihi titik optimum disebabkan oleh meningkatnya jumlah zat anorganik yang terkandung dalam koagulan yang tidak dapat didegradasi karena jumlahnya yang berlebihan dalam sampel uji. Akibatnya sisa zat anorganik maupun organik yang tidak dapat terdegradasi tersebut akan mengakibatkan naiknya hasil pengujian COD pada sampel uji limbah cair dengan dosis koagulan lebih besar dari dosis optimum.

\subsection{Pengaruh penambahan koagulan abu laying teraktivasi terhadap kekeruhan}

Kekeruhan atau turbiditas merupakan parameter yang harus diukur untuk mengetahui efektivitas proses koagulasi-flokulasi.

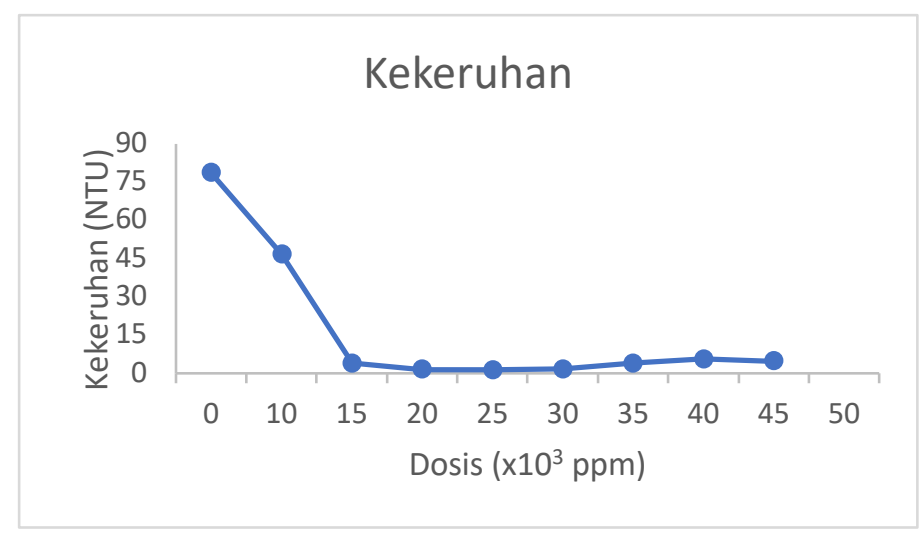

Gambar 4. Grafik Penurunan Nilai Kekeruhan

Akibat Penambahan Koagulan Abu Layang Teraktivasi

Dosis optimum penggunaan koagulan abu layang teraktivasi adalah pada konsentrasi $30000 \mathrm{ppm}$. Hal ini dilihat dari nilai turbiditas terendah. Kekeruhan pada air disebabkan oleh adanya zat padat tersuspensi, baik zat organik maupun zat anorganik. Zat anorganik biasanya berupa lapukan batuan, pasir, lumpur, dan logam terlarut. Sedangkan zat organik berasal dari buangan limbah domestik maupun industri yang dapat menjadi makanan bakteri dan perkembangbiakkan bakteri. Selain itu mikroorganisme, alga, dan plankton juga dapat menyebabkan kekeruhan pada air. Mekanisme yang paling mungkin terjadi dalam proses koagulasi adalah adsorpsi dan netralisasi tegangan atau adsorpsi dan ikatan antar partikel yang tidak stabil. Dari kedua mekanisme tersebut, untuk menentukan mekanisme mana yang terjadi merupakan suatu hal yang sangat sukar karena kedua mekanisme tersebut mungkin terjadi secara simultan (Sutherland et al., 1994).

\subsection{Pengaruh penambahan koagulan abu laying teraktivasi terhadap warna}

Koagulasi-flokulasi merupakan proses yang bertujuan untuk menjernihkan air dengan mengendapkan padatan tersuspensi yang terdapat pada air sehingga senyawa-senyawa dalam air yang menyebabkan warna akan terendapkan oleh proses koagulasi-flokulasi.

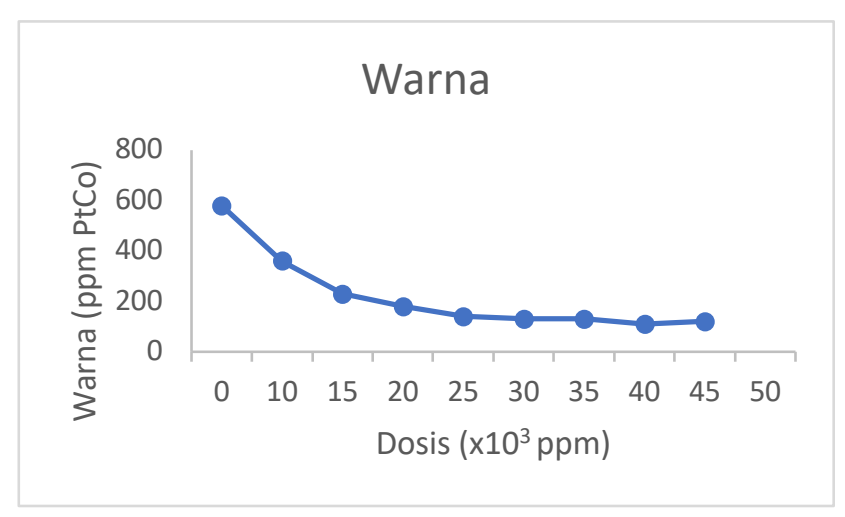

Gambar 5. Grafik Penurunan Nilai Warna

Akibat Penambahan Koagulan Abu Layang Teraktivasi 
Untuk standar warna pada limbah indsutri pulp dan kertas khususnya limbah cair pulp kraft yang dikelantang sesuai dengan Permen LH No. 5 Tahun 2014 pada Lampiran XXXV tentang Baku Mutu Air Limbah pada pulp kraft dikelantang tidak disebutkan atau tidak ada standar baku.

\subsection{Pengaruh penambahan koagulan abu laying teraktivasi terhadap nilai TSS}

Total suspended solid (TSS) merupakan sisa padatan yang tertinggal pada penyaringan atau dengan kata lain berat zat padat tersuspensi atau tak terlarut dalam volume tertentu dari limbah cair, masing-masing berupa bahan organik dan mineral (Salvato, 1972). Penetrasi sinar (cahaya) yang masuk ke dalam air bisa berkurang dengan adanya total suspended solid sehingga akan mempengaruhi regenerasi oksigen secara fotosintesis (Prayogo, 2006).

Proses koagulasi-flokulasi yang terjadi karena penambahan koagulan abu layang teraktivasi mampu menggumpalkan padatam tersuspensi dalam sampel limbah cair. Hal ini akan berdampak pada penurunan nilai total padatan tersuspensi dalam sampel uji dan juga berhubungan dengan penurunan nilai warna serta kekeruhan (turbiditas) sampel.

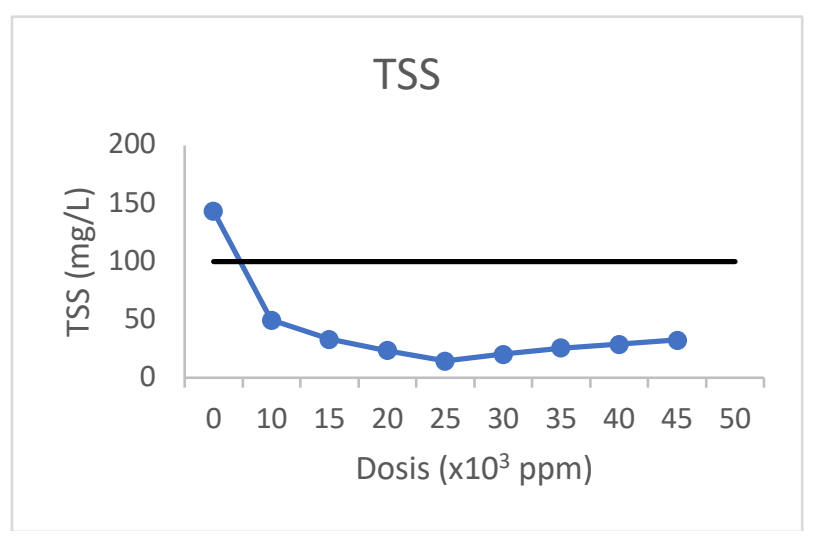

Gambar 6. Grafik Penurunan TSS

Akibat Penambahan Koagulan Abu Layang Teraktivasi

TSS terendah pada konsentrasi 30000 ppm dengan nilai $14,5 \mathrm{mg} / \mathrm{L}$. Untuk standar TSS pada limbah indsutri pulp dan kertas khususnya limbah cair pulp kraft yang dikelantang sesuai dengan Permen LH No. 5 Tahun 2014 pada Lampiran XXXV tentang Baku Mutu Air Limbah pada pulp kraft dikelantang yaitu sebesar $<100$ $\mathrm{mg} / \mathrm{L}$. Pada Gambar 5, disajikan grafik penurunan TSS dari percobaan koagulan abu layang teraktivasi, dimana hasilnya telah memenuhi standar yang ditetapkan oleh pemerintah. Dosis optimum koagulan abu layang teraktivasi berdasarkan penurunan TSS yaitu pada konsentrasi 30000 ppm yiatu dengan nilai TSS $14,5 \mathrm{mg} / \mathrm{L}$.

\subsection{Pengaruh penambahan koagulan abu layang teraktivasi terhadap perubahan konduktivitas}

Daya hantar dalam air sangat bervariasi, wilayah geografi yang berbeda memiliki perbedaan pula dalam tingkat kelarutan mineralnya karena itu tidak terdapat nilai standar tetapi tingginya nilai daya hantar dalam air minum tidak dibenarkan bagi konsumen (WHO, 2006).

Tabel 5. Variasi Dosis Koagulan Terhadap Konduktivitas

\begin{tabular}{|c|c|c|}
\hline No. & $\begin{array}{c}\text { Dosis } \\
(\mathrm{ppm})\end{array}$ & $\begin{array}{c}\text { Konduktivitas } \\
(\mu \mathrm{S} / \mathrm{cm})\end{array}$ \\
\hline 1 & 10000 & 6220 \\
\hline 2 & 15000 & 7290 \\
\hline 3 & 20000 & 11480 \\
\hline 4 & 25000 & 11800 \\
\hline 5 & 30000 & 12830 \\
\hline 6 & 35000 & 13050 \\
\hline
\end{tabular}




\begin{tabular}{|c|c|c|}
\hline No. & $\begin{array}{c}\text { Dosis } \\
(\mathrm{ppm})\end{array}$ & $\begin{array}{c}\text { Konduktivitas } \\
(\mu \mathrm{S} / \mathrm{cm})\end{array}$ \\
\hline 7 & 40000 & 13120 \\
\hline 8 & 45000 & 15800 \\
\hline 9 & 50000 & 17940 \\
\hline
\end{tabular}

Konduktivitas awal sampel yang belum dilakukan koagulasi yaitu 87,8 $\mu \mathrm{S} / \mathrm{cm}$. Konduktivitas dari sampel uji terus meningkat seiring meningkatnya dosis koagulan yang diberikan dalam proses. Penambahan koagulan abu layang teraktivasi akan menambah jumlah ion-ion dalam sampel dan mengakibatkan meningkatnya konduktivitas.

Tabel 6. Hasil Uji ICP Sampel Koagulan Abu Layang Teraktivasi dan Supernatan Proses Koagulasi

\begin{tabular}{|c|c|c|c|c|c|}
\hline \multirow{2}{*}{ Unsur } & \multirow{2}{*}{$\begin{array}{c}\text { Koagulan } \\
\text { Abu layang } \\
\text { teraktivasi }\end{array}$} & $\mathbf{2 0 0 0 0}$ & $\mathbf{2 5 0 0 0}$ & $\mathbf{3 0 0 0 0}$ & $\mathbf{3 5 0 0 0}$ \\
\cline { 3 - 6 } & & & & & \\
\hline $\mathrm{Ag}$ & 2,42 & $\mathrm{ND}$ & $\mathrm{ND}$ & $\mathrm{ND}$ & $\mathrm{ND}$ \\
\hline $\mathrm{Al}$ & 50831,6 & 0,83 & 1,5 & 1,70 & 2,2 \\
\hline $\mathrm{B}$ & 4220,08 & 12,9 & 16,4 & 19,74 & 20,59 \\
\hline $\mathrm{Ba}$ & 2,44 & 0,185 & 0,175 & 0,2 & 0,16 \\
\hline $\mathrm{Ca}$ & 52366,2 & 167,01 & 267,99 & 284,29 & 316,64 \\
\hline $\mathrm{Cd}$ & 2,98 & $\mathrm{ND}$ & $\mathrm{ND}$ & $\mathrm{ND}$ & $\mathrm{ND}$ \\
\hline $\mathrm{Co}$ & 24,64 & $\mathrm{ND}$ & $\mathrm{ND}$ & $\mathrm{ND}$ & $\mathrm{ND}$ \\
\hline $\mathrm{Cr}$ & 70,46 & $\mathrm{ND}$ & $\mathrm{ND}$ & $\mathrm{ND}$ & $\mathrm{ND}$ \\
\hline $\mathrm{Cu}$ & 298,42 & $\mathrm{ND}$ & $\mathrm{ND}$ & $\mathrm{ND}$ & $\mathrm{ND}$ \\
\hline $\mathrm{Fe}$ & 22892,1 & 0,37 & 0,14 & 0,26 & 0,57 \\
\hline $\mathrm{K}$ & 24186,82 & 387,15 & 403,11 & 424,42 & 438,36 \\
\hline $\mathrm{Li}$ & 538,2 & 1,17 & 1,63 & 2,03 & 2,16 \\
\hline $\mathrm{Mg}$ & 48202,12 & 38,88 & 94,42 & 120,56 & 117,06 \\
\hline $\mathrm{Mn}$ & 1073,86 & 0,01 & 1,005 & 3,66 & 0,995 \\
\hline $\mathrm{Na}$ & 47515,68 & 9351,67 & 10464,95 & 11496,12 & 12950,8 \\
\hline $\mathrm{Ni}$ & 61,2 & $\mathrm{ND}$ & $\mathrm{ND}$ & $\mathrm{ND}$ & $\mathrm{ND}$ \\
\hline $\mathrm{Pb}$ & 0,92 & $\mathrm{ND}$ & $\mathrm{ND}$ & $\mathrm{ND}$ & $\mathrm{ND}$ \\
\hline $\mathrm{Zn}$ & 194,16 & 0,02 & 0,11 & 0,11 & 0,18 \\
\hline
\end{tabular}

Dari hasil pengujian ICP seperti yang ditunjukkan oleh Tabel 6, beberapa logam yang terdeteksi menggunakan metode ini terlihat kandungan Al dan Fe yeng berperan dalam proses koagulasi merupakan unsur dengan jumlah yang banyak, yaitu berturut-turut 50831,6 dan 22892,1 ppb. Nilai ini akan terus terdegradasi seiring bereaksinya $\mathrm{Al}$ dan Fe sebagai koagulan pada limbah cair. Sedangkan, unsur $\mathrm{Na}, \mathrm{Mg}$, $\mathrm{K}$ dan $\mathrm{Ca}$ yang jumlahnya cukup banyak dalam koagulan abu layang teraktivasi. Unsur $\mathrm{Na}$ dan $\mathrm{K}$ merupakan logam alkali golongan IA sedangkan $\mathrm{Mg}$ dan Ca merupakan unsur dari golongan IIA yaitu logam alkali tanah. Unsur-unsur ini tidak terdegradasi sempurna dalam air hasil pengolahan. Sehingga, sisa dari unsur-unsur tersebut yang masih terdapat dalam supernatan air hasil pengolahan meningkatkan kesadahan air dan keelektronegatifan sehingga nilai konduktivitas dari air hasil olahan akan semakin meningkat seiring bertambahnya dosis koagulan abu layang teraktivasi yang diberikan. 


\section{Kesimpulan dan saran}

\subsection{Kesimpulan}

Berdasarkan hasil yang diperoleh pada penelitian ini, dapat diambil beberapa kesimpulan sebagai berikut:

1. Proses aktivasi abu layang dengan $\mathrm{H}_{2} \mathrm{SO}_{4}$ mendapatkan kondisi optimum pada penggunaan $\mathrm{H}_{2} \mathrm{SO}_{4}$ $2 \mathrm{M}$ dengan rasio abu layang terhadap $\mathrm{H}_{2} \mathrm{SO}_{4}$ sebesar 1:5 pada temperatur $250^{\circ} \mathrm{C}$ selama 60 menit, dengan yield $\mathrm{Al}$ dan $\mathrm{Fe}$ masing-masing sebesar $38,87 \%$ dan $14,5 \%$.

2. Dosis optimum koagulan abu layang teraktivasi dari penelitian ini yaitu pada $30000 \mathrm{ppm}$ dengan penurunan COD sebesar 81,5\% , penurunan TSS sebesar 96,2\%, penurunan warna sebesar 99,3\%, dan penurunan turbiditas sebesar $86,5 \%$.

3. Jika dibandingkan dengan Permen LH No. 5 Tahun 2014 tentang Baku Mutu Air Limbah untuk pulp kraft dikelantang, nilai-nilai hasil pengolahan dengan koagulan abu layang teraktivasi memberikan hasil yang masih dibawah nilai stnadar baku mutu yang diperbolehkan.

4. Penambahan koagulan abu layang teraktivasi pada pengolahan limbah cair mengakibatkan naiknya nilai konduktivitas limbah hasil olahan.

\subsection{Saran}

Berdasarkan hasil penelitian yang telah dilakukan, adapun saran untuk penelitian ini adalah sebagai berikut:

1. Melakukan variasi waktu pengadukan dan kecepatan pengadukan untuk melihat ada atau tidak pengaruh dari waktu dan kecepatan pengaduknya.

2. Perlu dilakukan peninjauan kembali apabila akan menggunakan koagulan untuk skala yang lebih besar, baik aspek lingkungan maupun biayanya.

3. Melakukan pengujian karakteristik dan muatan flok yang terbentuk saat flokulasi.

\section{Daftar pustaka}

Akpor, O. B., Ohiobor, G. O., \& Olaolu, T. D., Heavy Metal Pollutants in Wastewater Effluents: Sources, Effects and Remediation, Advances in Bioscience and Bioengineering, Vol. 2, No. 4, pp. 37-43 (2014)

Alaerts, G. dan S.S. Santika, Metoda Penelitian Air (Usaha Nasional, Surabaya, 1987)

Atkins, P. W., Kimia Fisik, Terjemahan Irma I. Kartohadiprodjo, Jilid 2, Edisi keempat, Erlangga, Jakarta (1996)

Davis, M.L. dan D.A. Cornwell, Introduction to Environmental Engineering (McGraw-Hill Inc., Singapura. 1991)

Fan, M., Brown, R. C., Wheelock, T. D., \& Cooper, A. T., Production Of A Complex Coagulant from Fly Ash, Chemical Engineering Journal, Vol. 106, Page : 269-277 (2005)

Hammer, M.J., Water and Wastewater Technology (Prentice-Hall Int. Inc., New Jersey. 1986)

Kementerian Lingkungan Hidup. Peraturan Menteri Lingkungan Hidup Tentang Baku Mutu Air Limbah. (Jakarta: Keputusan Menteri Lingkungan Hidup NO. 5/MENLH/2014)

Li L.S., Wu Y.S., Liu Y.Y ., Zhai Y.C., Extraction of Alumina from Coal Fly Ash with Sulfuric Acid Leaching Method, The Chinese Journal of Process Engineering, Vol. 11 (2), Page : 254-258. (2011)

Metcalf dan Eddy, Wastewater Engineering (Third Edition, McGraw-Hill International Edition, Singapura. 1991)

Muchjidin, Pengendalian Mutu dalam Industri Batubara, (Penerbit ITB Press, Bandung. 2006)

Safutra, Y., Amin, B., Anita, S., Potensi Limbah Abu Layang (Coal Fly Ash) Sebagai Koagulan Cair Dalam

Pengolahan Air Gambut, Dinamika Lingkungan Indonesia, Vol. 4 (2), Page : 99-108. (2017)

SNI, Pengujian Kualitas Air Sumber dan Limbah Cair, (Direktorat Pengembangan Lab Rujukan dan Pengolahan Data, BAPEDAL, Jakarta. 2004)

Sukandarrumidi, Batubara dan Pemanfaatannya, (Gadjah Mada University Press, Yogyakarta. 2009)

Sunardi, 116 Unsur Kimia, Deskripsi dan Pemanfaatannya, (Yrama Widya, Bandung. 2007)

Tim Kajian Batubara Nasional, Kelompok Kajian Kebijakan Mineral dan Batubara, Batubara Indonesia, (Pusat Litbang Teknologi Mineral dan Batubara. 2006)

Viraraghavan. T., Ash Utilization In Water Quality Management, (Faculty of Engineering, University of Regina, Canada. 1993) 